\title{
Congenital Anomalies of the Kidney and the Urinary Tract in Newborns from Lviv Region (West Ukraine) For 2006-2017
}

\author{
Kitsera $N^{*}$, Helner $N$, Osadchuk Z and Lukyanenko $N$ \\ Institute of Hereditary Pathology, National Academy of Medical Sciences of Ukraine, Ukraine
}

\begin{abstract}
Congenital anomalies of the kidney and the urinary tract (CAKUTs) are relatively common birth defects.

Aim of our study was to assess the frequency in newborns congenital anomalies of the kidney and the urinary tract from Lviv region (Ukraine) for 2006-2017 according to the medical reports by the maternity hospitals.

Methods: 272 newborns from Lviv region (West Ukraine) who were diagnosed according to the reporting form by the maternity hospitals with congenital anomalies of the kidney and the urinary tract were analyzed over a period of 12 years.

Results: During the study period (2006-2017), there were 342,894 births reported, and 8144 newborns were with congenital anomaly, an average incidence of 23.8 per 1000 births. There were 272 cases of CAKUT, an average incidence of 0.8 per 1000 births. The lowest frequency of CAKUT was observed 0.5 per 1000 newborns in 2008, 2013, 2015, 2017 years. The high frequency of this pathology - 1.1 -1.2 per 1000 newborns was diagnosed in 2011-2012 years.

The most common birth defects of the kidney and urinary tract in newborns in Lviv region were congenital hydronephrosis - 137 (50.4\%) and polycystic kidney - 72 (26.5\%).

Less commonly in newborns diagnosed other specified congenital malformations of kidney - 14 (5.2\%) and Potter sequence - $13(4.8 \%)$.

Conclusion: The importance of this study resides, to the best of our knowledge, in the fact that the largest group of patients in Ukraine was analyzed and assessed. Our study of the occurrence of urinary malformations in Lviv region (West Ukraine) for the 2006 to 2017 period showed wave-like dependence.
\end{abstract}

\section{Keywords}

Congenital anomalies, Kidney, Urinary tract, CAKUT, Newborns, Ukraine

\section{Introduction}

Congenital anomalies of the kidney and the urinary tract (CAKUTs) are relatively common birth defects [1-3]. Congenital anomalies of the kidney and urinary tract (CAKUT) represent a broad range of disorders that result from abnormalities of the urinary collecting system, abnormal embryonic migration of the kidneys, or abnormal renal parenchyma development [4]. The risk factors for these anomalies are not clearly identified and include many factors [5-7]. The pathogenesis of CAKUT is not well understood, because identifying the genetic architecture of CAKUT is difficult due to the phenotypic heterogeneity and multifactorial genetic penetrance $[8,9]$

Broad phenotypic spectrum of CAKUT and variability in genotype-phenotype correlation indicate that pathogenesis of CAKUT is a complex process that depends on interplay of many factors $[10,11]$.

The condition may appear as an isolated feature or as part of a syndrome in association with extra-renal manifestations [12-14].

The majority of Congenital Anomalies of the Kidney and Urinary Tract (CAKUT) with emphasis in pediatric pathology as varied as ureteral duplications, horseshoe kidney, posterior urethral valve and prune belly syndrome, ureteropelvic junction obstruction, obstructive renal dysplasia, nonmotile

*Corresponding author: Kitsera N, Institute of Hereditary Pathology, National Academy of Medical Sciences of Ukraine, Lviv, Ukraine

Accepted: July 13, 2019

Published online: July 15, 2019

Citation: Kitsera N, Helner N, Osadchuk Z, et al. (2019) Congenital Anomalies of the Kidney and the Urinary Tract in Newborns from Lviv Region (West Ukraine) For 2006-2017. Arch Gene Genome Res 2(1):33-37 
Citation: Kitsera N, Helner N, Osadchuk Z, et al. (2019) Congenital Anomalies of the Kidney and the Urinary Tract in Newborns from Lviv Region (West Ukraine) For 2006-2017. Arch Gene Genome Res 2(1):33-37

ciliopathies and several syndromes associated with renal malformations (Potter, renal adysplasia, short rib, Meckel-Joubert, asplenia/polysplenia, Bardet-Biedl, hereditary Zellweger, trisomies, VACTER-L, caudal dysplasia and sirenomelia) [1,15-19].

Renal-Coloboma Syndrome (renal hypoplasia and coloboma, caused by PAX2 mutations), Orofaciodigital Syndrome (associated with renal cysts, caused by OFD1 gene mutations), Branchio-Oto-Renal Syndrome (caused by mutations in EYA1, SIX1 and SIX5 genes), Renal cysts and Diabetes Syndrome (associated with mutations in HNF1B gene), Fraser Syndrome (characterized by eye abnormalities, syndactyly and various CAKUT forms, caused with mutations in $F R$ AS1, FREM2 or GRIP1 genes), Alagille Syndrome (bile ducts abnormalities, facial features, heart and kidney malformations, for JAG1 and NOTCH1 mutations), and Townes-Brocks Syndrome (imperforate anus, hands and ears malformations and kidney abnormalities, caused by SALL1 mutations) $[12,16,18,20-22]$.

In 1995, the first gene defect described as being causative of CAKUT was a frameshift deletion in PAX2 in a family with optic nerve coloboma, renal hypoplasia and vesicoureteral reflux [21]. PAX2 plays a critical role in kidney development and its mutations (more than 55 have been reported so far) can lead to different isolated CAKUT phenotypes [22].

CAKUT cover a wide range of structural malformations that result from a defect in the morphogenesis of the kidney and/or the urinary tract $[15,23,24]$.

Congenital anomalies of kidney and urinary tract (CAKUT) are observed in 3-6 per 1,000 live births and account for 40$50 \%$ of the etiology of chronic kidney disease (CKD) in children worldwide [2].

At the same time, Tain YL, et al. notes that birth defects of the kidney and urinary tract and glomerular disease are the most common diagnoses of kidney disease in childhood; the incidence of congenital anomalies of the kidney and urinary tract during the past decade has been estimated to be 0.4 to 4.0 cases per 1000 births [9]. In France of the 1678 infants with CAKUT born during 26 years in 346,831 consecutive births prevalence at birth was 4.8 per 1,000 [25].

EUROCAT submits cases and prevalence (per 1,000 births) for all full member registries from 2012 to 2016 yy of uri- nary -3.5 , of congenital hydronephrosis -1.3 , bilateral renal agenesis including Potter syndrome -0.1 [26]. Prevalence in Ukraine (Rivne, Khmelnycky) the pathology of urinary was 3.1 per 1000 newborns [5] in 2005-2015, congenital hydronephrosis -1.2 , bilateral renal agenesis including Potter syndrome -0.08 [27].

Aim of our study was to assess the frequency of congenital anomalies of the kidney and the urinary tract in newborns for 2006-2017 yy. According to the medical reports by the maternity hospitals from Lviv region (West Ukraine).

\section{Materials and Methods}

This retrospective study evaluated 272 newborns with congenital anomalies of the kidney and the urinary tract who were diagnosed over a period of 12 years (2006-2017) according to the reporting form submitted by the maternity hospitals from Lviv region (West Ukraine).

Inclusion criteria - newborns with congenital anomalies of the kidney and the urinary tract. Exclusion criteria - newborns with multiple birth defects or other syndromes except Potter sequence.

All patients were assessed with physical examination and underwent a set of diagnostic tests including general clinical tests, family history, complicated childbirth, abdominal ultrasonography (if needed) in maternity hospitals. Congenital anomalies in newborns were recorded by birth obstetrician in a birth defects form. In addition we analysed the following data for each patient: Sex and birthplace.

\section{Results}

According to the Statistical Office on January, 2017 population [28] was 2,534,000 persons, including 1,323,300 women (52.2\%) in Lviv region (West Ukraine). The smallest number of newborns was in 2017 - 26,452, the largest number of newborns was in 2014 - 30,270 (Table 1). The prevalence of all birth defects were 958 and 948 cases in 2006-2007 years and the lowest number - 495 cases in 2017 year and 525 cases in 2008 year (Table 1). The percentage of all malformations ranged from $1.8 \% 2008$ year to $3.5 \%$ in $2006-2007$ years which corresponds to the general population data in Ukraine [23].

We studied cohort of newborns from 20 districts of Lviv region and Lviv town (2006-2017) according to the medical re-

Table 1: Frequency of birth defects of the kidney and urinary tract in newborns from Lviv region (West Ukraine) by year, 2006 to 2017.

\begin{tabular}{|l|l|l|l|l|l|l|l|l|l|l|l|l|l|}
\hline & 2006 & 2007 & 2008 & 2009 & 2010 & 2011 & 2012 & 2013 & 2014 & 2015 & 2016 & 2017 & $2006-2017$ \\
\hline Number of newborns & 27272 & 27454 & 29007 & 30079 & 28651 & 28904 & 30220 & 29542 & 30270 & 27909 & 27134 & 26452 & $\mathbf{3 4 2 8 9 4}$ \\
\hline All BD & 958 & 948 & 525 & 641 & 643 & 656 & 711 & 695 & 664 & 633 & 575 & 495 & $\mathbf{8 1 4 4}$ \\
\hline \% & 3.5 & 3.5 & 1.8 & 2.1 & 2.2 & 2.3 & 2.4 & 2.4 & 2.2 & 2.3 & 2.1 & 1.9 & $\mathbf{2 . 4}$ \\
\hline $\begin{array}{l}\text { BD of the kidney and } \\
\text { Urinary tract }\end{array}$ & 27 & 17 & 14 & 27 & 27 & 33 & 37 & 16 & 20 & 15 & 25 & 14 & 272 \\
\hline $\begin{array}{l}\text { Frequency BD of the } \\
\text { kidney and Urinary tract } \\
1: 1000\end{array}$ & 1 & 0.6 & 0.5 & 0.9 & 0.9 & 1.1 & 1.2 & 0.5 & 0.7 & 0.5 & 0.9 & 0.5 & 0.8 \\
\hline
\end{tabular}

BD - Birth defects. 
Citation: Kitsera N, Helner N, Osadchuk Z, et al. (2019) Congenital Anomalies of the Kidney and the Urinary Tract in Newborns from Lviv Region (West Ukraine) For 2006-2017. Arch Gene Genome Res 2(1):33-37

cords from maternity hospitals. Newborns out come from the maternity hospital three days after the birth child. So in the first days of the birth doctor can not confirm this pathology. Early diagnosis is inadequate as clinical manifestations of congenital anomalies of the kidney and the urinary tract and appear only in the case of adherence to infections, or by prenatal ultrasonography.

During the period (2006-2017) of study, there were 342 894 births reported, and 8144 newborns had congenital anomaly, an average incidence of 23.8 per 1000 births. There were 272 cases of CAKUT, an average incidence of 0.8 per 1000 births (Table 1). The lowest frequency of CAKUT was observed 0.5 per 1000 newborns in 2008, 2013, 2015, 2017 years. The high frequency of this pathology - $1.1-1.2$ per 1000 newborns was diagnosed in 2011-2012 years.

Our cohort included 272 newborns (149 boys and 123 girls) with congenital anomalies of the kidney and the urinary tract (103 from village and 169 newborns from town). Every year were found 14-37 newborns with congenital anomalies of the kidney and the urinary tract (Table 2 ) in the Lviv region. The largest number of cases (33-37) was registered in 2011 -2012 years, the smallest - 14 cases in of CAKUT in 2008 and 2017 years.

The most common birth defects of the kidney and urinary tract (Table 2) were congenital hydronephrosis - 137 (50.4\%) and polycystic kidney - $72(26.5 \%)$ in newborns from Lviv region (West Ukraine).

Table 2 shows the trend of incidence of congenital anomalies and CAKUT over time. Very rarely was met renal dysplasia - $1(0.4 \%)$ and other congenital malformations of bladder and urethra - $1(0.4 \%)$. The same frequency had been established of renal hypoplasia and congenital single renal cyst - 6 cases (2.2\%). The spectrum of congenital anomalies of the kidney and urinary tract was extremely broad and range from mild (asymptomatic malformations such as a double ureter or minimal ureteral pelvic obstructions) to severe (lifethreatening pathologies like bilateral renal agenesis or renal dysplasia).

Less commonly other specified congenital malformations of kidney - 14 (5.2\%) and Potter sequence - 13 (4.8\%) was diagnosed in newborns (Table 2).

\section{Discussion}

Hildebrandt F. notes that the frequency of CAKUT is 3-6 per 1,000 live births [2] but frequency of this pathology in Lviv region (West Ukraine) in 2011-2012 is 1.1-1.2 on 1000 newborns. This frequency in the Lviv region is lower than in other regions of Ukraine [5] and in France [25] but higher than in Taiwan [9]. The discrepancy in reported incidence is likely to be related to the ethnic differences, the method of diagnosis, size of the study population and the way in which the birth defect information used was recorded.

Congenital anomalies of the kidney and urinary tract continue to be a group of diseases with different degrees of severity and many of them require a multidisciplinary approach for accurate diagnosis and better treatment [1].

For doctors it is very important to establish the correct diagnosis in order to facilitate adequate genetic counseling and to alert the families of other possible affected members that could benefit from earlier intervention $[1,15,29]$.

Since the spectrum of CAKUT is different and heterogeneous various studies predominate in variety birth defects $[10,16,24]$. In our study prevalence congenital hydronephrosis and polycystic kidney. Most often congenital hydronephrosis diagnosed among all the defects $[4,10]$.

Several of these renal abnormalities are part of a syndrome or sequence (especially Potter sequence) that can be

Table 2: Spectrum of congenital anomalies of the kidney and urinary tract in newborns from Lviv region (West Ukraine) by year, 2006 to 2017.

\begin{tabular}{|c|c|c|c|c|c|c|c|c|c|c|c|c|c|c|}
\hline \multicolumn{2}{|c|}{ Diagnosis/years } & \multirow{2}{*}{$\begin{array}{l}2006 \\
1\end{array}$} & \multirow{2}{*}{\begin{tabular}{|l}
2007 \\
0
\end{tabular}} & \multirow{2}{*}{$\begin{array}{l}2008 \\
0\end{array}$} & \multirow{2}{*}{$\begin{array}{l}2009 \\
1\end{array}$} & \multirow{2}{*}{$\begin{array}{l}2010 \\
1\end{array}$} & \multirow{2}{*}{$\begin{array}{l}2011 \\
0\end{array}$} & \multirow{2}{*}{$\begin{array}{l}2012 \\
2\end{array}$} & \multirow{2}{*}{$\begin{array}{l}2013 \\
0\end{array}$} & \multirow{2}{*}{$\begin{array}{l}2014 \\
1\end{array}$} & \multirow{2}{*}{\begin{tabular}{|l|}
2015 \\
1 \\
\end{tabular}} & \multirow{2}{*}{$\begin{array}{l}2016 \\
0\end{array}$} & \multirow{2}{*}{$\begin{array}{l}2017 \\
1\end{array}$} & \multirow{2}{*}{$\begin{array}{l}2006-2017 \\
8\end{array}$} \\
\hline Q60.0 & Renal agenesis & & & & & & & & & & & & & \\
\hline Q60.6 & Renal hypoplasia & 1 & 2 & 1 & 0 & 0 & 0 & 0 & 2 & 0 & 0 & 0 & 0 & 6 \\
\hline Q60.7 & Potter sequence & 1 & 0 & 0 & 1 & 2 & 2 & 2 & 0 & 1 & 1 & 0 & 3 & 13 \\
\hline Q61.0 & Congenital single renal cyst & 0 & 0 & 0 & 0 & 0 & 1 & 0 & 0 & 0 & 0 & 5 & 0 & 6 \\
\hline Q61.3 & Polycystic kidney & 10 & 2 & 2 & 2 & 7 & 7 & 9 & 5 & 6 & 4 & 10 & 8 & 72 \\
\hline Q61.4 & Renal dysplasia & 0 & 0 & 0 & 0 & 0 & 0 & 0 & 0 & 0 & 0 & 0 & 1 & 1 \\
\hline Q62.0 & Congenital hydronephrosis & 6 & 7 & 7 & 21 & 17 & 21 & 23 & 9 & 12 & 5 & 8 & 1 & 137 \\
\hline Q63.0 & Accessory kidney & 1 & 0 & 0 & 0 & 0 & 0 & 1 & 0 & 0 & 2 & 1 & 0 & 5 \\
\hline Q63.8 & $\begin{array}{l}\text { Other specified congenital } \\
\text { malformations of kidney }\end{array}$ & 5 & 6 & 2 & 0 & 0 & 1 & 0 & 0 & 0 & 0 & 0 & 0 & 14 \\
\hline Q63.9 & $\begin{array}{l}\text { Congenital } \\
\text { malformation of kidney, } \\
\text { Unspecified }\end{array}$ & 2 & 0 & 1 & 2 & 0 & 1 & 0 & 0 & 0 & 2 & 1 & 0 & 9 \\
\hline \multirow[t]{2}{*}{ Q64.7 } & $\begin{array}{l}\text { Other congenital } \\
\text { malformations of bladder } \\
\text { and urethra }\end{array}$ & 0 & 0 & 1 & 0 & 0 & 0 & 0 & 0 & 0 & 0 & 0 & 0 & 1 \\
\hline & All & 27 & 17 & 14 & 27 & 27 & 33 & 37 & 16 & 20 & 15 & 25 & 14 & 272 \\
\hline
\end{tabular}


Citation: Kitsera N, Helner N, Osadchuk Z, et al. (2019) Congenital Anomalies of the Kidney and the Urinary Tract in Newborns from Lviv Region (West Ukraine) For 2006-2017. Arch Gene Genome Res 2(1):33-37

confirmed and sometimes treated by a multidisciplinary approach including fetal ultrasonography and vesico-amniotic shunt placement to relieve obstruction while in the fetal period, or by other imaging modalities, molecular analysis, and pathologic examination after birth $[1,5,30]$.

Potter sequence refers to a group of features that can result when there is too little amniotic fluid (oligohydramnios) surrounding a baby while in the uterus. This can cause distinct facial features (Potter facies), which may include a flattened nose, recessed chin, skin folds covering the corners of the eyes (epicanthal folds), and low-set abnormal ears. Having low amniotic fluid can also result in underdevelopment of the lungs (pulmonary hypoplasia). Other associated features may include eye malformations and heart defects $[1,3,17,25]$.

In first of all the Potter sequence was diagnosed on base of facial features typical of babies with this syndrome. In our cohort we diagnosed 13 (4.8\%) newborns with Potter sequence -8 boys and 5 girls. Among these newborns 7 had bilateral renal agenesis and 6 -polycystic kidney diseases. Signs that might be identified on ultrasound include kidney abnormalities.

Although the most severely affected newborns progress within the first year of life, doctors have problems with early diagnosis of CAKUT. This review focuses on the genetic mechanisms (single-gene mutations, modifier genes) leading to renal system anomalies in patients and discusses emerging insights into the role of epigenetics, in utero environmental factors in the pathogenesis of CAKUT $[3,5,10]$.

One of the possible problems underdiagnosis of CAKUT is clinically asymptomatic and doctors may be found only when are actively sought, or are diagnosed by prenatal ultrasonography in the latter period of pregnancy. The natural course of CAKUT is very heterogeneous $[11,15,24,25]$. Although the most severely affected newborns progress this pathology within the first few months of life, kidney function improves in most children born with CAKUT, typically reaching a peak around age 3-4 years.

The study is also important as it may help to raise the awareness of surgical pediatric intervention and to emphasize the loss of babies with congenital abnormalities.

\section{Conclusion}

1. The percentage of all malformations ranged from $1.8 \%$ 2008 year to $3.5 \%$ in 2006-2007 years in Lviv region (West Ukraine) which corresponds to the general population data in Ukraine.

2. We studied 272 newborns with congenital anomalies of the kidney and the urinary tract who was diagnosed of 12 years (2006-2017) from Lviv region (West Ukraine). Frequency of this pathology of this period was 0.8 on 1000 newborns. The high frequency of this pathology - $1.1-1.2$ per 1000 newborns was diagnosed in 2011-2012 years.

3. Spectrum of congenital anomalies of the kidney and urinary tract is very different. The most common were congenital hydronephrosis - 137 (50.4\%) and polycystic kidney - 72 (26.5\%). Less commonly in newborns diagnosed other specified congenital malformations of kidney - 14 (5.2\%) and Potter sequence - 13 (4.8\%).

4. Newborns out come from the maternity hospital three days after the birth child. So in the first days of the birth doctor can not confirm this pathology. Early diagnosis is inadequate as clinical manifestations of congenital anomalies of the kidney and the urinary tract and appear only in the case of adherence to infections, or by prenatal ultrasonography.

The importance of this study resides, to the best of our knowledge, in the fact that the largest group of patients in Ukraine was analyzed and assessed. Our study of the occurrence of urinary malformations in Lviv region (West Ukraine) for the 2006 to 2017 period showed wave-like dependence.

\section{References}

1. Rodriguez MM (2014) Congenital_anomalies_of_the_kidney_ and_the_urinary_tract_CAKUT Fetal Pediatr Pathol 33: 293-320.

2. Hildebrandt F (2010) Genetic kidney diseases. Lancet 375: 12871295.

3. https://www.icd10data.com/ICD10CM/Codes/Q00-Q99/ Q60-Q64

4. dos Santos Junior AC, de Miranda DM, Simoes e Silva AC (2014) Congenital anomalies of the kidney and urinary tract: An embryogenetic review. Birth Defects Res C Embryo Today 102: 374-381.

5. Nicolaou N, Renkema KY, Bongers EM, et al. (2015) Genetic, environmental, and epigenetic factors involved in CAKUT. Nat Rev Nephrol 11: 720-731.

6. TV Sorokman, VG Ostapchuk, OV Makarova (2017) Hereditary and familial diseases and malformations of kidneys in childhood.

7. Groen In 't Woud S, Renkema KY, Schreuder MF, et al. (2016) Maternal risk factors involved in specific congenital anomalies of the kidney and urinary tract: A case-control study. Birth Defects Res A Clin Mol Teratol 106: 596-603.

8. Lee KH, Gee HY, Shin JI (2017) Genetics of vesicoureteral reflux and congenital anomalies of the kidney and urinary tract. Investig Clin Urol 58: S4-S13.

9. Tain YL, Luh H, Lin CY, et al. (2016) Incidence and risks of congenital anomalies of kidney and urinary tract in newborns: A population-based case-control study in Taiwan. Medicine (Baltimore) 95: e2659.

10. Song R, Yosypiv IV (2011) Genetics of congenital anomalies of the kidney and urinary tract. Pediatr Nephrol 26: 353-364.

11. Kim JH, Park EY, Chitayat D, et al. (2019) SON haploinsufficiency causes impaired pre-mRNA splicing of CAKUT genes and heterogeneous renal phenotypes. Kidney Int Mar 15.

12. Eccles MR, Schimmenti LA (1999) Renal-coloboma syndrome: A multi-system developmental disorder caused by PAX2 mutations. Clin Genet 56: 1-9.

13. Capone VP, Morello W, Taroni F, et al. (2017) Genetics of congenital anomalies of the kidney and urinary tract: The current state of play. Int J Mol Sci 18: 796.

14. Vivante A, Kohl S, Hwang D, et al. (2014) Single-gene causes of congential anomalies of the kidney and urinary tract (CAKUT) in 
Citation: Kitsera N, Helner N, Osadchuk Z, et al. (2019) Congenital Anomalies of the Kidney and the Urinary Tract in Newborns from Lviv Region (West Ukraine) For 2006-2017. Arch Gene Genome Res 2(1):33-37

humans. Pediatr Nephrol 29: 695-704.

15. Ishiwa S, Sato M, Morisada N, et al. (2019) Association between the clinical presentation of congenital anomalies of the kidney and urinary tract (CAKUT) and gene mutations: An analysis of 66 patients at a single institution. Pediatr Nephrol 34: 1457-1464.

16. Fu-Jun Lin, Wei Lu, Daniel Gale, et al. (2016) Delayed diagnosis of Townes-Brocks syndrome with multicystic kidneys and renal failure caused by a novel SALL1 nonsense mutation: A case report. Exp Ther Med 11: 1249-1252.

17. https://www.ncbi.nlm.nih.gov/omim

18. Deng L, Liu Y, Xia W, et al. (2019) Identification of ANLN as a new likely pathogenic gene of branchio-otic syndrome in a threegeneration Chinese family. Mol Genet Genomic Med 7: e00525.

19. Kohl S, Hwang DY, Dworschak GC, et al. (2014) Mild recessive mutations in six Fraser syndrome-related genes cause isolated congenital anomalies of the kidney and urinary tract. J Am Soc Nephrol 25: 1917-1922.

20. Vivante A, Chacham OS, Shril S, et al. (2019) Dominant PAX2 mutations may cause steroid-resistant nephrotic syndrome and FSGS in children. Pediatr Nephrol.

21. Sanyanusin P, Schimmenti L, McNoe L, et al. (1995) Mutation of the PAX2 gene in a family with optic nerve colobomas, renal anomalies and vesicoureteral reflux. Nat Genet 9: 358-364.
22. Bower M, Salomon R, Allanson J, et al. (2012) Update of PAX2 mutations in renal coloboma syndrome and establishment of a locus-specific database. Hum Mutat 33: 457-466.

23. Lanovenko E (2017) Dynamics of Congenital Development Disorders Prevalence in Ukrainian Regions and their Structure in Kherson Region. Ukr J Medicine Biology Sport 4: 175-179.

24. Sanna-Cherchi S, Westland R, Ghiggeri GM, et al. (2018) Genetic basis of human congenital anomalies of the kidney and urinary tract. J Clin Invest 128: 4-15.

25. Stoll C, Dott B, Alembik Y, et al. (2014) Associated nonurinary congenital anomalies among infants with congenital anomalies of kidney and urinary tract (CAKUT). Eur J Med Genet 57: 322-328.

26. http://www.eurocat-network.eu/accessprevalencedata/ prevalencetables

27. http://www.eurocatnetwork.eu/prevdata/resultsPdf.

28. http://www.lv.ukrstat.gov.ua/

29. Chesnaye N, Bonthuis M, Schaefer F, et al. (2014) Demographics of paediatric renal replacement therapy in Europe: A report of the ESPN/ERA-EDTA registry. Pediatr Nephrol 29: 2403-2410.

30. Andres-Jensen L, Jorgensen FS, Thorup J, et al. (2016) The outcome of antenatal ultrasound diagnosed anomalies of the kidney and urinary tract in a large Danish birth cohort. Arch Dis Child 101: 819-824. 